\title{
PENGARUH PERSEPSI DAN KEPUASAN KONSUMEN TERHADAP MINAT PEMBELIAN ULANG PRODUK PRIVATE LABEL INDOMARET (STUDI PADA KONSUMEN INDOMARET DI KECAMATAN TELANAIPURA KOTA JAMBI)
}

\author{
Firdaus \\ Staf Pengajar Program Studi Ilmu Pemerintahan STISIP Nurdin Hamzah, Jambi \\ Corresponding author: firdaussudirmanz@gmail.com
}

\begin{abstract}
Abstrak
Tujuan penelitian ini adalah untuk menguji pengaruh persepsi konsumen dan kepuasan konsumen terhadap minat pembelian ulang produk private label indomaret. Sampel penelitian yang digunakan sebanyak 96 orang responden, dimana data dari sampel dikumpulkan menggunakan kuesioner untuk kemudian dianalisis dengan teknik analisis regresi berganda. Hasil analisis statistik membuktikan bahwa secara parsial dan secara simultan persepsi konsumen dan kepuasan konsumen berpengaruh signifikan terhadap minat pembelian ulang produk private label indomaret. Hasil penelitian ini berimplikasi terhadap upaya peritel indomaret dalam peningkatan nilai produk, melalui penyesuaian antara manfaat produk dengan harga yang harus dibayarkan oleh konsumen, dikarenakan persepsi nilai merupakan aspek persepsi memiliki kontribusi pengaruh terbesar bagi minat pembelian ulang. Di samping itu, juga diperlukan upaya menjaga konsistensi dalam menentukan kebijakan harga yang sesuai dengan kualitas produk yang diberikan.
\end{abstract}

Kata kunci: persepsi konsumen, kepuasan konsumen, minat pembelian ulang, private label

\begin{abstract}
The purpose of this study was to examine the effect of consumer perception and customer satisfaction on repurchase interest of Indomaret private label products. The research sample used was 96 respondents, where data from the sample was collected using a questionnaire to then be analyzed with multiple regression analysis techniques. The results of statistical analysis prove that partially and simultaneously consumer perception and customer satisfaction have a significant effect on repurchase interest of Indomaret private label products. The results of this study have implications for the efforts of Indomaret retailers in increasing the value of products, through adjustments between product benefits and prices to be paid by consumers, because the perception of value is the aspect of perception having the greatest influence contribution to repurchase interest. In addition, efforts are also needed to maintain consistency in determining pricing policies that are in accordance with the quality of the product provided.
\end{abstract}

Keywords: consumer perception, customer satisfaction, repurchase interest, private label

\section{PENDAHULUAN}

Persaingan bisnis ritel yang semakin ketat membuat keberadaan merek menjadi sangat penting, mengingat merek bukan hanya sekedar nama atau simbol tetapi suatu pembeda produk lainnya sekaligus menegaskan persepsi kualitas dari produk tersebut 
(Andriyanto, 2009). Banyak para peritel yang berusaha mengembangkan mereknya sendiri dalam persaingan dengan merek-merek nasional lainnya yang biasa disebut private label atau private brand dan digunakan sebagai produk substitusi terhadap produk merek nasional yang pada umumnya menawarkan harga yang lebih tinggi.

Salah satu usaha ritel yang mengembangkan produk private brand adalah PT. Indomarco Prismatama dengan membuka Indomaret sebagai retailnya. Indomaret mengeluarkan produk private label dengan tujuan bisa menghadirkan produk dengan harga yang lebih murah, namun dengan kualitas yang tidak jauh dengan produk umum yang dijual. Di gerai indomaret, barang private label menempati rak golden (rak khusus) agar mudah terlihat konsumen. Indomaret juga menawarkan harga yang terjangkau untuk produk-produk private label dengan penghematan harga mencapai $10 \%$ - 20\% dari harga produk berlabel nasional.

Data penjualan produk private label di salah satu gerai Indomaret Buluran Kenali Kecamatan Telanaipura Kota Jambi, menunjukkan bahwa rata-rata penjualan produk sepanjang bulan Maret Hingga November 2019 hanya sebanyak 26 produk per bulan. Dari data ini pula diketahui bahwa dari 10 produk private label, air mineral merupakan produk dengan total penjualan tertinggi, kemudian diikuti dengan cotton buds refill dan facial cotton. Merujuk pada data penjualan ini, tentunya dibutuhkan upaya dalam meningkat minat beli ulang produk tersebut agar penjualannya semakin meningkat.

Nilai untuk membeli kembali suatu produk akan muncul ketika pelanggan merasa bahwa produk yang digunakannya bisa memberikan kepuasan terhadap diri pelanggan tersebut. Bila pelanggan puas pada pembelian pertama, maka pembelian berikutnya cenderung akan dilakukan secara berulang-ulang pada satu merek, sehingga pengambilan keputusan tidak lagi diperlukan karena pelanggan telah mengetahui secara mendalam mengenai merek tersebut (Tatik, 2008). Hasil temuan Anggoro (2016) dalam penelitiannya membuktikan bahwa kepuasan pelanggan memiliki pengaruh yang signifikan terhadap minat beli ulang.

Untuk mencapai kepuasan pelanggan, tentunya banyak hal yang mempengaruhi pelanggan merasa puas atas produk yang akan dikonsumsinya. Salah satu faktor tersebut adalah mengenai persepsi konsumen terhadap atribut yang melekat pada produk, terutama untuk produk private label yang dijual oleh indomaret. Menurut Beneke, dkk (2013) produk private label dapat dipersepsikan oleh empat aspek yaitu; citra toko, harga produk, kualitas produk, dan nilai produk.

Citra toko merupakan salah satu elemen penting dari usaha ritel yang mampu mempengaruhi proses keputusan pembelian konsumen, karena dalam proses keputusan pembeliannya konsumen tidak hanya memberi respon terhadap barang dan jasa yang ditawarkan oleh pengecer, tetapi juga memberikan respon terhadap lingkungan pembelian yang diciptakan oleh pengecer. Apabila toko tersebut mempunyai citra yang baik dimata konsumen maka konsumen pun akan setia berbelanja di toko tersebut (Alimah, 2017:5). Di sisi lain persepsi konsumen mengenai harga akan sangat berpengaruh apakah konsumen akan berminat untuk mengkonsumsi suatu produk. Semakin positif persepsi konsumen terhadap harga suatu produk, maka akan semakin kuat kecenderungan konsumen untuk membeli ulang produk tersebut (Liu \& Tingko, 2016).

Persepsi mengenai kualitas produk juga menjadi faktor penentu bagi minat konsumen untuk melakukan pembelian ulang suatu produk. Bao, dkk (2011) dalam penelitiannya menyatakan bahwa persepsi kualitas berpengaruh signifikan terhadap minat membeli konsumen dan kecenderungan untuk membeli produk private label. 
Terkait dengan pengalaman konsumen menggunakan jasa atau produk yang pernah dibeli, pada dasarnya konsumen melakukan evaluasi atas nilai yang diperoleh dari pengalaman pembelian sebelumnya, dan mengaitkannya dengan manfaat yang diperoleh sebagai penentu harapan konsumen dalam pembelian selanjutnya (Li \& Hong, 2013). Dengan demikian persepsi nilai yang diberikan konsumen terhadap suatu produk private label dipredikisikan juga dapat mempengaruhi minat pembelian ulang produk tersebut. Beberapa kajian empiris yang dilakukan sebelumnya telah membuktikan bahwa persepsi nilai memberikan pengaruh positif terhadap miat beli ulang (Jen \& Hu, 2003; Kusdyah, 2012; Raza dkk, 2012;).

Hasil survey awal terhadap 15 orang responden (konsumen produk private label indomaret) mengenai persepsi terhadap produk private label yang ada di gerai indomaret Buluran Kenali Kecamatan Telanaipura menunjukkan bahwa pada aspek citra toko, 10 orang atau $66,6 \%$ responden setuju bahwa gerai indomaret memiliki reputasi yang baik dalam hal keragaman produk, jaminan kualitas dan keamanan, dan pelayanan. Sementara dari aspek persepsi harga, 12 orang atau $80 \%$ responden setuju bahwa harga produk private label indomaret lebih murah dibanding produk sejenis merek lainnya. Untuk aspek persepsi kualitas produk, 9 orang atau $60 \%$ menyatakan setuju bahwa produk private label indomaret memiliki kualitas yang sebanding dengan merek pabrikan aslinya atau merek lain. Pada aspek persepsi nilai, 11 orang atau $68,75 \%$ menyatakan puas terhadap nilai yang dirasakan dari produk private label indomaret. Hasil survey awal kepuasan konsumen menunjukkan bahwa 12 orang atau $80 \%$ responden setuju bahwa produk private label indomaret dapat memenuhi kebutuhan konsumen dengan baik sehingga dapat memberikan kepuasan bagi konsumen. Namun, di sisi lain hasil survey awal mengenai minat pembelian ulang didapatkan hanya 7 orang atau $46,6 \%$ konsumen yang ingin melakukan pembelian ulang produk private label indomaret.

Merujuk pada uraian teori, hasil temuan terdahulu, serta fenomena perilaku pembelian produk private label indomaret yang diduga diakibatkan oleh oleh adanya pengaruh dari kepuasan konsumen dan persepsi konsumen terhadadap citra toko, harga, nilai, dan kualitas produk, maka perlu dilakukan kajian empiris lebih lanjut untuk mengungkap sejauh mana pengaruh dari persepsi dan kepuasan konsumen terhadap minat beli ulang produk private label indomaret di gerai Indomaret Kecamatan Telanaipura.

\section{LANDASAN TEORI}

\subsection{Minat Pembelian Ulang}

Minat membeli merupakan dorongan konsumen untuk melakukan pembelian atau dorongan yang dimiliki oleh seseorang untuk melakukan pembelian ulang. Hellier et.al (2003) menyatakan bahwa repurchase intention (pembelian ulang) merupakan penilaian individu yang berkaitan dengan membeli ulang pada sebuah layanan atau sebuah produk pada satu perusahaan yang sama, dengan mempertimbangkan keadaan dan situasi mereka.

Sahin dan Kitapci (2012) mengemukakan bahwa terdapat tiga indikator untuk mengukur minat pembelian ulang, yaitu:

1) Minat repeat order

Terjadi apabila konsumen merespon positif terhadap produk sehingga mereka akan melakukan pembelian secara terus - menerus terhadap produk yang menarik perhatian. 
2) Minat preferensial

Minat preferensial merupakan minat yang menggambarkan perilaku seseorang yang memiliki preferensi utama pada produk tersebut, preferensi ini dapat berubah bila terjadi sesuatu dengan produk preferensinya.

3) Minat eksploratif

Minat eksploratif menggambarkan perilaku seseorang yang selalu mencari informasi mengenai produk yang diminatinya dan mencari informasi untuk mendukung sifat-sifat positif dari produk tersebut.

\subsection{Persepsi}

Persepsi adalah proses dimana seseorang memiling, mengatur dan menterjemahkan masukan informasi yang diterima untuk menciptakan gambaran dunia yang lebih berarti. Persepsi tidak hanya tergantung pada rangsangan fisik, tetapi juga pada hubungan rangsangan terhadap bidang yang mengelilinginya dan kondisi dalam diri orang itu (Kotler dan Armstrong, 2008). Menurut Beneke, dkk (2013) produk private label dapat dipersepsikan oleh empat aspek yaitu; citra toko, harga produk, kualitas produk, dan nilai produk.

1) Persepsi citra toko

Menurut Simamora (2003), citra toko adalah kepribadian sebuah toko yang menggambarkan apa yang dilihat dan dirasakan oleh konsumen terhadap toko tersebut. Terdapat dua faktor yang mendukung citra toko, yaitu faktor external impression dan faktor internal impression.

\subsection{External impression}

Secara eksternal penempatan lokasi toko, desain arsitek, penempatan logo, pintu masuk serta etalase muka toko merupakan bagian dari citra suatu toko.

\subsection{Internal impression}

Secara internal, citra sebuah toko dapat diciptakan menurut warna toko, bentuk toko, ukuran toko, penempatan departemen, pengaturan lalu lintas pengunjung, penempatan display, penggunaan lampu, serta pemilihan perlengkapan toko.

2) Persepsi harga

Persepsi harga adalah sejumlah nilai yang dipertukarkan untuk memperoleh suatu produk bagi konsumen yang sensitif biasanya harga murah adalah sumber kepuasan yang penting karena mereka akan mendapatkan value for money yang tinggi (Irawan, dalam Ningsih, 2017). Menurut Kotler dan Armstong (2008) dalam Yuwan Soelistio (2016) ada empat indikator yang digunakan dalam mengukur persepsi harga, yaitu: (1) keterjangkauan harga, (2) kesesuaian harga dengan kualitas produk dan layanan, (3) daya saing harga, (4) kesesuaian harga dengan manfaat.

3) Persepsi kualitas

Persepsi kualitas (perceived quality) menurut Aaker (1997) dapat didefinisikan sebagai persepsi pelanggan terhadap keseluruhan kualitas atau keunggulan suatu produk atau jasa layanan berkaitan dengan apa yang diharapkan oleh pelanggan. Menurut Kotler dan Armstrong (2008), terdapat enam dimensi kualitas yang perlu diperhatikan, yaitu: (1) mutu kinerja (performance), (2) keandalan (reliability), (3) keistimewaan (feature), (4) daya tahan (durability), (5) mutu kesesuaian (conformance quality), dan (6) gaya (style). 
4) Persepsi nilai

Zeithaml dan Bitner (1996) mendefinisikan persepsi nilai sebagai penilaian konsumen secara keseluruhan terhadap kegunaan suatu produk atau jasa berdasarkan persepsi atas apa yang telah didapat. Menurut Sweeny, dkk dalam Tjiptono (2011), persepsi nilai pelanggan terdiri dari tiga dimensi, yaitu: (1) emotional value, (2) social value, dan (3) quality/performance value.

\subsection{Kepuasan Konsumen}

Menurut Kotler dan Keller (2007), kepuasan adalah perasaan senang atau kecewa seseorang yang muncul setelah membandingkan kinerja produk yang dirasakan terhadap kinerja produk yang diharapkan. Dalam menentukan kepuasan konsumen ada lima faktor yang harus diperhatikan oleh perusahaan (Lupiyoadi, 2006) antara lain:

1) Kualitas produk, yaitu pelanggan akan merasa puas bila hasil mereka menunjukkan bahwa produk yang mereka gunakan berkualitas.

2) Kualitas pelayanan atau jasa, yaitu pelanggan akan merasa puas bila mereka mendapatkan pelayanan yang baik atau sesuai dengan yang diharapkan.

3) Emosi, yaitu pelanggan akan merasa bangga dan mendapatkan keyakinan bahwa orang lain akan kagum terhadap dia bila menggunakan produk dengan merek tertentu yang cenderung mempunyai tingkat kepuasan yang lebih tinggi. Kepuasan yang diperoleh bukan karena kualitas dari produk tetapi sosial atau self esteem yang membuat konsumen merasa puas terhadap merek tertentu.

4) Harga, yaitu produk yang mempunyai kualitas yang sama tetapi menetapkan harga yang relatif murah akan memberikan nilai yang lebih tinggi kepada konsumen.

5) Biaya, yaitu pelanggan yang tidak perlu mengeluarkan biaya tambahan atau tidak perlu membuang waktu untuk mendapatkan suatu produk atau jasa cenderung puas terhadap produk atau jasa tersebut.

\section{METODE PENELITIAN}

Penelitian ini menggunakan rancangan penelitian survey, yang bertujuan untuk mendeskripsikan dan menganalisis hubungan antar variabel yang diteliti, yaitu; variabel persepsi konsumen, variabel kepuasan konsumen, dan variabel minat pembelian ulang. Adapun ukuran sampel yang diambil atau digunakan dalam penelitian ini adalah sebanyak 96 orang responden, yang diperoleh dengan menggunakan teknik accidental sampling.

Untuk mengetahui besarnya pengaruh persepsi konsumen dan kepuasan konsumen terhadap minat pembelian ulang dilakukan pengukuran terhadap variabelvariabel penelitian. Untuk maksud tersebut, dilakukan operasionalisasi variabel yaitu menjabarkan variabel ke dalam indikator, ukuran dan skala pengukuran. Sesuai dengan variabel-variabel yang akan diukur, maka operasional variabel penelitian ini adalah sebagai berikut:

Tabel 3.1. Operasionalisasi Variabel Penelitian

\begin{tabular}{|l|l|l|c|}
\hline \multicolumn{1}{|c|}{ Variabel } & \multicolumn{1}{|c|}{ Dimensi } & \multicolumn{1}{c|}{ Indikator } & Skala \\
\hline \multirow{3}{*}{$\begin{array}{l}\text { Persepsi } \\
\text { konsumen }\end{array}$} & \multirow{3}{*}{$\begin{array}{l}\text { Persepsi citra } \\
\text { toko }\end{array}$} & Lokasi toko & Ordinal \\
\cline { 2 - 3 } $\begin{array}{l}\text { 2013; Kotler } \\
\text { dan }\end{array}$ & & Tata letak produk & Ordinal \\
\cline { 2 - 4 } Armstrong, & \multirow{2}{*}{\begin{tabular}{l} 
Persepsi \\
\cline { 2 - 4 }
\end{tabular}} & Keragaman jenis produk & Ordinal \\
\cline { 2 - 4 } & Pengalaman berbelanja & Ordinal \\
\cline { 2 - 4 } & Keterjangkauan harga & Ordinal \\
\cline { 2 - 4 } & Daya saing harga & Ordinal \\
\cline { 2 - 4 } & Kesesuaian harga dengan manfaat & Ordinal \\
\hline
\end{tabular}




\begin{tabular}{|c|c|c|c|}
\hline \multirow{6}{*}{$\begin{array}{l}\text { 2008; Putra, } \\
\text { 2018; Tjiptono, } \\
\text { 2011) }\end{array}$} & \multirow{3}{*}{$\begin{array}{l}\text { Persepsi } \\
\text { kualitas }\end{array}$} & Keandalan (reliability) & Ordinal \\
\hline & & Daya tahan (durability) & Ordinal \\
\hline & & Mutu kesesuaian (conformance quality) & Ordinal \\
\hline & \multirow{3}{*}{ Persepsi nilai } & Emotional value & Ordinal \\
\hline & & Social value & Ordinal \\
\hline & & Quality/performance value & Ordinal \\
\hline \multirow{9}{*}{$\begin{array}{l}\text { Kepuasan } \\
\text { konsumen } \\
\text { (Lupiyoadi, } \\
\text { 2006) }\end{array}$} & \multirow{3}{*}{$\begin{array}{l}\text { Kualitas } \\
\text { produk }\end{array}$} & Kesesuaian kinerja produk dengan harapan konsumen & Ordinal \\
\hline & & $\begin{array}{l}\text { Kesetaraan kualitas produk private label dengan } \\
\text { merek produk lainnya }\end{array}$ & Ordinal \\
\hline & & Jaminan keamanan produk & Ordinal \\
\hline & \multirow{4}{*}{$\begin{array}{l}\text { Kualitas } \\
\text { pelayanan }\end{array}$} & $\begin{array}{l}\text { Pelayanan karyawan toko dalam menerima keluhan } \\
\text { atau kritik }\end{array}$ & Ordinal \\
\hline & & $\begin{array}{l}\text { Ketanggapan karyawan dalam memenuhi permintaan } \\
\text { konsumen }\end{array}$ & Ordinal \\
\hline & & $\begin{array}{l}\text { Empati karyawan dalam menghadapi keluhan } \\
\text { konsumen }\end{array}$ & Ordinal \\
\hline & & $\begin{array}{l}\text { Kemampuan karyawan dalam melayani kebutuhan } \\
\text { konsumen }\end{array}$ & Ordinal \\
\hline & \multirow[b]{2}{*}{ Harga } & Kesesuaian harga dengan mutu produk & Ordinal \\
\hline & & $\begin{array}{l}\text { Perbandingan harga produk private label dengan } \\
\text { produk merek lainnya }\end{array}$ & Ordinal \\
\hline \multirow{7}{*}{$\begin{array}{l}\text { Minat } \\
\text { Pembelian } \\
\text { Ulang } \\
\text { (Sahin dan } \\
\text { Kitapci, 2012) }\end{array}$} & \multirow{2}{*}{$\begin{array}{l}\text { Minat repeat } \\
\text { order }\end{array}$} & $\begin{array}{l}\text { Berniat untuk melakukan pembelian ulang produk } \\
\text { private label }\end{array}$ & Ordinal \\
\hline & & Akan selalu menggunakan produk private label & Ordinal \\
\hline & \multirow{2}{*}{$\begin{array}{l}\text { Minat } \\
\text { preferensial }\end{array}$} & $\begin{array}{l}\text { Membeli/ menggunakan ulang produk private label } \\
\text { setelah mendengar rekomendasi dari orang lain }\end{array}$ & Ordinal \\
\hline & & $\begin{array}{l}\text { Berniat membeli/ menggunakan ulang produk private } \\
\text { label karena manfaatnya baik }\end{array}$ & Ordinal \\
\hline & \multirow{3}{*}{$\begin{array}{l}\text { Minat } \\
\text { eksploratif }\end{array}$} & $\begin{array}{l}\text { Ingin mencoba variasi lain dari produk private label } \\
\text { indomaret }\end{array}$ & Ordinal \\
\hline & & $\begin{array}{l}\text { Ingin mencari tahu lebih jauh manfaat dari produk } \\
\text { private label indomaret }\end{array}$ & Ordinal \\
\hline & & $\begin{array}{l}\text { Ingin membeli/ menggunakan produk private label } \\
\text { indomaret karena banyak variasinya sesuai dengan } \\
\text { kebutuhan }\end{array}$ & Ordinal \\
\hline
\end{tabular}

Data hasil pengisian kuesioner yang telah diperoleh kemudian dianalisis dengan menggunakan teknik regresi linear berganda. Menurut Sugiyono (2009:275) analisis regresi berganda merupakan analisis yang digunakan untuk menguji pengaruh dua atau lebih variabel independen terhadap variabel dependen yang digambarkan dalam bentuk model persamaan.. Analisis data dalam penelitian ini dibantu dengan software SPSS21.

Untuk mengetahui apakah model regresi liner berganda dapat dinyatakan sebagai model yang baik, maka model tersebut harus memenuhi kriteria BLUE (Best Linear Unbiased Estimator). Untuk memenuhi kriteria tersebut maka dilakukan uji asumsi klasik. Menurut Setyadharma (2010:2) sedikitnya terdapat empat uji asumsi klasik yang harus dilakukan terhadap suatu model regresi linier berganda, yaitu; uji normalitas, uji autokorelasi, uji multikolinearitas, dan uji heteroskedastisitas.

\section{IV.HASIL DAN PEMBAHASAN}

\subsection{Hasil Penelitian}

\subsubsection{Deskripsi Variabel Penelitian}

Hasil pengukuran terhadap semua dimensi variabel penelitian memiliki kriteria nilai yang tinggi yaitu dengan rentang nilai 3,43 - 4,23. Untuk variabel persepsi konsumen, dari hasil pengukuran keempat dimensi yang merefleksikannya (citra toko, 
harga, kualitas, dan nilai), didapatkan bahwa dimensi persepsi nilai mendapatkan ratarata nilai tertinggi dibandingkan dimensi lainnya. Hal ini menerangkan bahwa persepsi konsumen terhadap produk private label indomaret cenderung dipengaruhi oleh penilaian konsumen yang didapatkan dari hasil perbandingan antara kinerja produk berdasarkan utilitasnya dengan biaya yang dikeluarkan untuk mendapatkan produk tersebut.

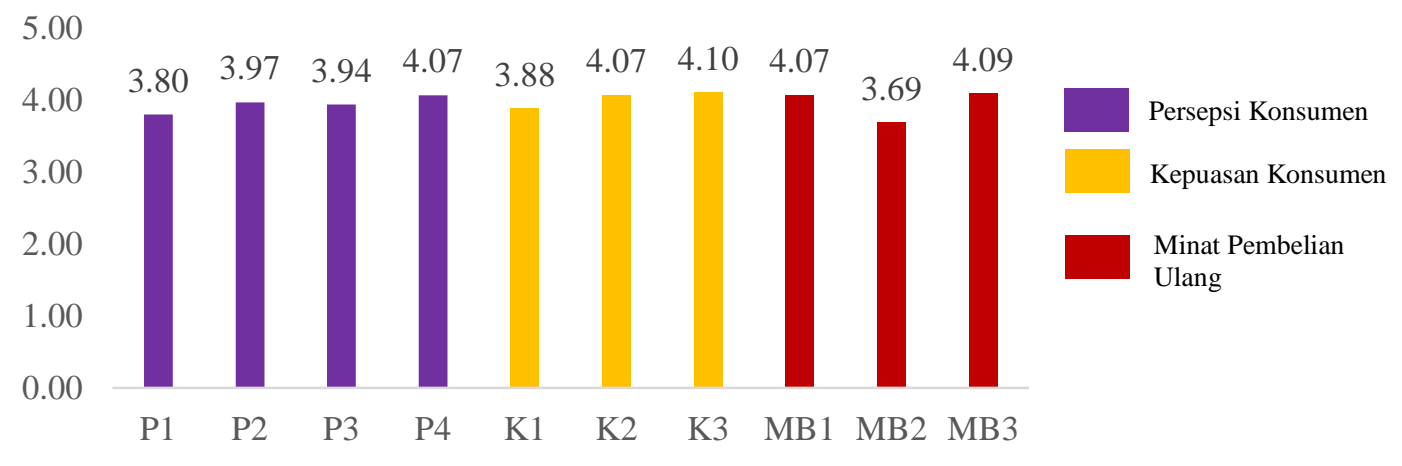

Gambar 4.1

Hasil Tanggapan Responden untuk Variabel Persepsi Konsumen, Kepuasan Konsumen, dan Minat Pembelian Ulang

Keterangan:

$\mathrm{P} 1 \quad=$ Persepsi citra toko

P2 = Persepsi harga

P3 = Persepsi kualitas

$\mathrm{P} 4=$ Persepsi nilai

$\mathrm{K} 1=$ Kualitas produk

$$
\begin{array}{ll}
\text { K2 } & =\text { Kualitas pelayanan } \\
\text { K3 } & =\text { Harga } \\
\text { MB1 } & =\text { Minat repeat order } \\
\text { MB2 } & =\text { Minat preferensial } \\
\text { MB3 } & =\text { Minat eksploratif }
\end{array}
$$

Hasil pengukuran ketiga dimensi yang merefleksikan variabel kepuasan konsumen (kualitas produk, kualitas pelayanan, dan harga), didapatkan bahwa dimensi harga mendapatkan rata-rata nilai tertinggi dibandingkan dimensi lainnya. Hal ini menerangkan bahwa kepuasan konsumen cenderung dipengaruhi oleh harga produk private label indomaret, dimana produk tersebut memiliki kualitas yang tidak jauh berbeda dengan merek nasional atau lainnya, namun memberikan harga yang relatif lebih murah. Hal ini dibuktikan dari respon yang diberikan konsumen dimana sebagian besar responden (konsumen) menyatakan bahwa produk private label indomaret memiliki harga yang sesuai dengan mutu produknya, dan harga tersebut jauh lebih murah dari produk sejenis yang diproduksi oleh merek nasional atau merek lainnya.

Tanggapan responden untuk ketiga dimensi pengukuran variabel minat pembelian ulang (minat repeat order, minat preferensial, dan minat eksploratif), didapatkan bahwa dimensi minat eksploratif mendapatkan rata-rata nilai tertinggi dibandingkan dimensi lainnya. Hal ini menerangkan bahwa minat pembelian ulang produk private label indomaret cenderung terjadi karena adanya dorongan keinginan untuk; (1) mencoba variasi lain dari produk private label indomaret, (2) mencari tahu lebih jauh manfaat dari produk private label indomaret, dan (3) membeli/ menggunakan produk private label indomaret karena banyak variasinya sesuai dengan kebutuhan.

\subsubsection{Uji Asumsi Klasik}

1) Uji Normalitas

Uji ini dilakukan untuk mengetahui apakah data yang diperoleh berasal dari populasi yang berdistribusi normal atau tidak. Data dapat dinyatakan berdistribusi secara normal jika nilai sig (signifikansi atau nilai probabilitas) yang diperoleh dari 
hasil pengujian lebih besar dari 0,05. Berdasarkan hasil uji Kolmogorov-Smirnov, didapatkan nilai signifikansi sebesar 0,911, dimana 0,911 >0,05. Dengan demikian dapat disimpulkan bahwa data dalam penelitian ini diambil dari populasi yang berdistribusi normal.

\section{2) Uji Autokorelasi}

Uji ini dilakukan untuk mendeteksi ada tidaknya autokorelasi pada model regresi liner yang didapatkan. Berdasarkan uji Cochrane Orcutt, yang telah didapatkan dengan berbantuan program analisis statistik SPSS 21, didapat nilai Durbin Watson (DW) sebesar 2,016. Nilai DW ini berada pada rentang dU (1,7103) - 4-Du $(2,2897)$, yang berarti bahwa model dinyatakan tidak mengalami gejala autokorelasi.

\section{3) Uji Multikolinieritas}

Uji multikolinearitas digunakan untuk mengetahui ada atau tidaknya penyimpangan asumsi klasik multikolinearitas yaitu adanya hubungan linear antar variabel independen dalam model regresi. Pedoman dalam mendapatkan keputusan ada tidaknya gejala multikolinearitas yaitu dengan menghitung nilai VIF dari setiap variabel independen. Bila nilai VIF lebih besar dari 10 maka model regresi liner tersebut memiliki gejala multikolinearitas, sedangkan bila nilai VIF lebih kecil dari 10 maka model regresi liner tersebut tidak memiliki gejala multikolinearitas.

Berdasarkan hasil perhitungan nilai VIF dengan berbantuan program analisis statistik SPSS 21, didapatkan nilai VIF untuk setiap variabel yang diujikan, didapatkan bahwa variabel persepsi konsumen, kepuasan konsumen, dan minat pembelian ulang memiliki nilai VIF lebih kecil dari 10. Dengan demikian dapat disimpulkan bahwa model regresi linier yang didapatkan tidak memiliki gejala multikolinearitas, artinya model regresi linier telah memenuhi persyaratan.

\section{4) Uji Heteroskedastisitas}

Dalam penelitian ini dilakukan uji scatterplot dengan alat bantu SPSS, untuk mengetahui apakah model mengalami gejala heteroskedastisitas atau tidak. Berdasarkan hasil pengujian, didapatkan bahwa pada scatterplot titik hasil pengolahan data antara ZPRED dan SRESID menyebar di bawah maupun di atas titik origin (angka 0) pada sumbu Y dan tidak mempunyai pola teratur, dengan demikian dapat dinyatakan bahwa model tidak mengalami gejala heteroskedastisitas.

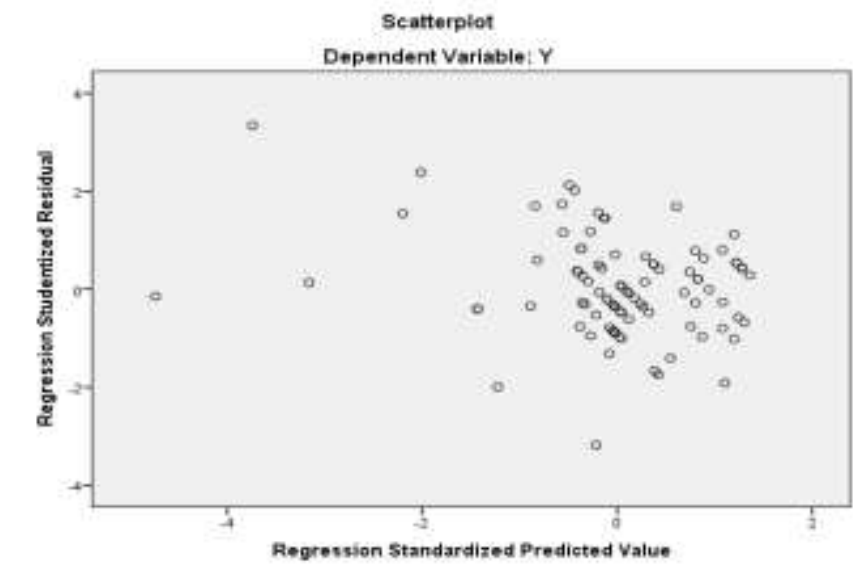

Hasil Uji Heteroskedastitas dengan Metode Scatterplot 


\subsubsection{Analisis Regresi Berganda}

Berdasarkan hasil perhitungan koefisien regresi melalui program SPSS 21 (Tabel 4.1) didapatkan model regresi berganda yaitu, $Y=3,811+0,190 X 1+0,396 X 2$. Dari model persamaan regresi tersebut, berarti minat pembelian ulang $(\mathrm{Y})$ akan mengalami peningkatan, bila persepsi konsumen (X1) dan kepuasan konsumen (X2) ditingkatkan.

Tabel 4.1

Hasil Perhitungan Koefesien Regresi dan Uji T Statistik

\begin{tabular}{|c|c|c|c|c|c|}
\hline \multirow{2}{*}{ Model } & \multicolumn{2}{|c|}{ Unstandardized Coefficients } & \multirow{2}{*}{$\begin{array}{c}\text { Standardized Coefficients } \\
\text { Beta }\end{array}$} & \multirow{2}{*}{$\mathbf{t}$} & \multirow{2}{*}{ Sig. } \\
\hline & $\mathbf{B}$ & Std. Error & & & \\
\hline (Constant) & 3,811 & 1,531 & & 2,489 & 015 \\
\hline $\mathrm{X} 1$ & $\mathbf{0 , 1 9 0}$ &, 051 & ,382 & 3,692 & ,000 \\
\hline $\mathrm{X} 2$ & 0,396 & 081 & ,506 & 4,892 &, 000 \\
\hline
\end{tabular}

Data pada Tabel 4.1 koefisien regresi untuk kepuasan konsumen $(\mathrm{X} 2)=0,396$ lebih besar daripada koefisien regresi persepsi konsumen $(X 1)=0,190$. Berdasarkan model persamaan regresi yang telah didapatkan yaitu: $\mathrm{Y}=3,811+0,190 \mathrm{X} 1+0,396 \mathrm{X} 2$, maka didapatkan gambaran pengaruh variabel persepsi konsumen (X1) dan kepuasan konsumen (X2) terhadap minat pembelian ulang (Y) sebagai berikut:

1. Konstanta (a) $=3,811$, artinya jika variabel persepsi konsumen (X1) dan kepuasan konsumen (X2) tidak ada, maka minat pembelian ulang (Y) akan meningkat atau bertambah nilainya sebesar 3,811.

2. Koefisien regresi $X 1\left(\beta_{1} X_{1}\right)=0,190$, artinya jika terjadi peningkatan persepsi konsumen sebesar $1 \%$, maka akan meningkatkan minat pembelian ulang sebesar $0,190 \%$.

3. Koefisien regresi $\mathrm{X} 2\left(\beta_{2} \mathrm{X}_{2}\right)=0,396$, artinya jika terjadi peningkatan kepuasan konsumen sebesar 1\%, maka akan meningkatkan minat pembelian ulang sebesar $0,396 \%$.

\subsubsection{Uji Koefisien Determinasi $\left(\mathbf{R}^{2}\right)$}

Hasil perhitungan nilai koefisien determinasi $\left(\mathrm{R}^{2}\right)$ melalui program SPSS 21 (Tabel 4.2) didapatkan nilai sebesar 0,732. Hal ini berarti variasi naik turunnya variabel minat pembelian ulang mampu dijelaskan oleh persepsi konsumen dan kepuasan konsumen sebesar 73,2 persen, sementara sisanya sebesar 26,8 persen diterangkan oleh variabel lainnya yang tidak diteliti dalam penelitian ini.

\subsubsection{Uji Hipotesis}

\section{1) Uji T Statistik}

Hasil uji t statistik melalui program SPSS 21 (Tabel 4.1) didapatkan nilai signifikansi (sig) untuk variabel persepsi konsumen (X1) sebesar 0,000, dimana nilai ini lebih kecil dari 0,05, dengan demikian didapatkan keputusan untuk menerima hipotesis pertama bahwa variabel persepsi konsumen berpengaruh signifikan terhadap variabel minat pembelian ulang $(Y)$. Sementara nilai signifikansi (sig) untuk variabel kepuasan konsumen (X2) $(0,000)$ juga lebih kecil dari 0,05, dengan demikian didapatkan keputusan untuk menerima hipotesis kedua bahwa variabel kepuasan konsumen berpengaruh signifikan terhadap variabel minat pembelian ulang (Y).

\section{2) Uji F Statistik}

Hasil uji f statistik melalui program SPSS 21 didapatkan nilai signifikansi (sig) sebesar 0,000, dimana nilai ini lebih kecil dari 0,05, yang berarti bahwa secara 
bersama-sama (simultan) persepsi konsumen (X1) dan kepuasan konsumen (X2) berpengaruh signifikan terhadap minat pembelian ulang $(\mathrm{Y})$ produk private label indomaret.

\subsection{Pembahasan}

\subsubsection{Pengaruh Persepsi Konsumen terhadap Minat Pembelian Ulang}

Hasil pengujian hipotesis membuktikan bahwa persepsi konsumen yang direfleksikan oleh citra toko, harga, kualitas produk, dan nilai, berpengaruh signifikan terhadap minat pembelian ulang produk private label indomaret. Dengan demikian semakin positif persepsi konsumen terhadap citra toko, harga, kualitas produk, dan nilai dari produk private label indomaret, maka semakin tinggi minat konsumen untuk melakukan pembelian ulang terhadap produk tersebut.

Citra toko (store image) mempunyai peranan yang sangat penting dalam hal perkembangan dan kesuksesan private label sebuah perusahaan ritel. Ketika konsumen mendapatkan persepsi yang positif akan suatu merek produk melalui citra tokonya, maka pelanggan tidak akan ragu untuk berkunjung kembali dan berniat melakukan pembelian ulang pada merek produk tersebut. Berbagai hasil temuan terdahulu, seperti penelitian; Liljander et al (2009), Beneke, dkk (2013), Yongchuan (2011), dan Hidayat dan Karneli (2018) membuktikan bahwa citra toko dapat mempengaruhi minat konsumen untuk melakukan pembelian ulang.

Produk private label diposisikan sebagai produk alternatif yang lebih murah dibandingkan dengan produk national brand (Hasanah, 2017). Konsumen di Indonesia sebagian besar mempunyai persepsi bahwa kualitas produk national brand dan private label sama baiknya. Hal ini terbukti dari tanggapan responden dalam penelitian ini, bahwa menurut mereka produk private label indomaret memiliki kualitas produk yang tidak jauh berbeda dengan produk national brand. Hasil penelitian Bao, dkk (2011), Ramadhan (2018), dan Manullang membuktikan bahwa persepsi kualitas berpengaruh signifikan terhadap minat pembelian ulang.

Hasanah (2017) dalam penelitiannya menyatakan bahwa alasan utama konsumen membeli produk private label adalah alasan harga namun dengan meningkatkan kualitas dari produk private label, maka konsumen akan tetap memilih produk private label dibandingkan dengan national brand. Kotler (2009) juga menegaskan bahwa konsumen memilih produk private label karena dapat menghemat biaya sebesar $30 \%$. Hasil penelitian Wang \& Chen (2016); Liu \& Tingko (2016); dan Ramadhan (2018) membuktikan bahwa persepsi harga yang sesuai akan memberikan pengaruh langsung terhadap minat beli ulang. Hal ini dapat terjadi, jika hasil evaluasi perbandingan harga dengan produk lain ataupun produk yang sama dengan penawaran harga yang berbeda telah sesuai dengan keinginan dan kemampuan konsumen.

Pengalaman konsumen terhadap produk private label yang pernah dibeli, dijadikan sebagai salah satu alasan melakukan evaluasi atas nilai yang diperoleh dari pengalaman pembelian sebelumnya, dan mengaitkannya dengan manfaat yang diperoleh sebagai penentu harapan konsumen dalam pembelian selanjutnya (Li \& Hong, 2013). Dengan demikian persepsi nilai yang diberikan konsumen terhadap suatu produk private label juga berperan penting bagi minat pembelian ulang terhadap produk tersebut diwaktu yang akan datang. Beberapa kajian empiris yang dilakukan oleh; Kusdyah (2012); Raza dkk (2012); dan Cahyono dan Al-Bari (2016), membuktikan bahwa persepsi nilai berpengaruh signifikan terhadap minat pembelian ulang. 


\subsubsection{Pengaruh Kepuasan Konsumen terhadap Minat Pembelian Ulang}

Hasil pengujian hipotesis membuktikan bahwa kepuasan konsumen yang direfleksikan oleh kualitas produk, kualitas pelayanan, dan harga berpengaruh signifikan terhadap minat pembelian ulang produk private label indomaret. Dengan demikian semakin tinggi kepuasan konsumen terhadap kualitas produk, kualitas pelayanan, dan harga produk private label indomaret, maka semakin tinggi minat konsumen untuk melakukan pembelian ulang terhadap produk tersebut. Hasil temuan dalam penelitian ini selaras dengan hasil penelitian Cahyono dan Al-Bari (2016); Purbasari dan Purnamasari (2018); Puspitasari (2006); dan Vista (2018) yang membuktikan bahwa kepuasan konsumen berpengaruh signifikan terhadap minat pembelian ulang.

Kepuasan konsumen merupakan aset yang penting bagi perusahaan karena dapat digunakan sebagai indikator atas kualitas dan pendapatan perusahaan dimasa mendatang. Kepuasan pelanggan merupakan hasil dari perbandingan antara harapan dan kenyataan yang diterima pelanggan setelah mengkonsumsi barang atau jasa. Berkaitan dengan kesetiaan pelanggan, Anderson, dkk (1994) menyatakan bahwa apabila pelanggan puas terhadap barang atau kualitas layanan yang diberikan maka akan timbul kesetiaan pelanggan sehingga minat beli pelanggan meningkat dan membuat pelanggan kembali melakukan pembelian ulang (repurchase).

Konsumen yang tidak merasa puas atas kualitas dan pelayanan yang diperoleh cenderung menimbulkan masalah, sebaliknya apabila mereka puas maka akan tercipta hubungan yang baik dan harmonis. Hal ini akan menjadi dasar yang baik bagi terciptanya pembelian ulang dan terciptanya loyalitas konsumen yang akan menguntungkan perusahaan. Terciptanya kepuasan konsumen dapat memberikan manfaat, diantaranya membentuk rekomendasi komunikasi lisan (Tjiptono, 2008). Konsumen akan membeli hanya dari satu pemasok dan menyebarkan berita yang baik tentang produk atau perusahaan melalui komunikasi, sehingga dapat dikatakan bahwa kepuasan konsumen dapat mempengaruhi minat pembelian ulang konsumen.

\subsubsection{Pengaruh Persepsi Konsumen dan Kepuasan Konsumen terhadap Minat Pembelian Ulang}

Minat untuk membeli kembali suatu produk akan muncul ketika konsumen merasa bahwa produk yang diterimanya bisa memberikan kepuasan terhadap diri konsumen tersebut. Bila konsumen puas pada pembelian pertama, maka pembelian berikutnya cenderung akan dilakukan secara berulang-ulang pada satu merek, sehingga pengambilan keputusan tidak lagi diperlukan karena konsumen telah mengetahui secara mendalam mengenai merek tersebut Tatik (2008), sehingga dapat diambil kesimpulan bahwa konsumen yang merasa puas atas pembelian yang dilakukan maka konsumen akan melakukan pembelian kembali.

Untuk mencapai kepuasan konsumen, tentunya banyak hal yang mempengaruhi konsumen merasa puas atas produk/jasa yang akan dikonsumsinya. Salah satu faktor tersebut adalah mengenai persepsi konsumen terhadap produk yang dikonsumsinya. Semakin positif persepsi konsumen terhadap citra toko, harga, kualitas produk, dan nilai dari produk private label indomaret, maka akan semakin meningkatkan perasaan positif konsumen dalam bentuk rasa puas, yang kemudian berdampak pada adanya dorongan berupa minat untuk melakukan pembelian ulang produk private label indomaret di waktu berikutnya. Hal ini terbukti dari hasil pengujian hipotesis yang 
menunjukkan bahwa persepsi konsumen dan kepuasan konsumen secara simultan berpengaruh signifikan terhadap minat pembelian ulang produk private label indomaret.

\section{SIMPULAN DAN SARAN}

\subsection{Kesimpulan}

1. Persepsi konsumen secara parsial berpengaruh signifikan terhadap minat pembelian ulang produk private label indomaret.

2. Kepuasan konsumen secara parsial berpengaruh signifikan terhadap minat pembelian ulang produk private label indomaret.

3. Persepsi konsumen dan kepuasan konsumen secara simultan berpengaruh signifikan terhadap minat pembelian ulang produk private label indomaret.

\subsection{Saran}

1. Hasil pengukuran variabel persepsi konsumen menunjukkan bahwa dimensi persepsi nilai mendapatkan hasil penilaian paling tinggi. Penilaian tersebut menunjukkan bahwa instrumen terbesar yang mampu mempengaruhi minat membeli ulang produk private label adalah melalui persepsi nilai. Maka, dengan demikian disarankan untuk peritel Indomaret agar mengukur terutama nilai fungsional dari produk private label demi keselarasan antara manfaat produk dengan harga yang harus dibayarkan oleh konsumen.

2. Hasil pengukuran variabel kepuasan konsumen menunjukkan bahwa dimensi harga mendapatkan hasil penilaian paling tinggi. Penilaian tersebut menunjukkan bahwa harga merupakan faktor yang paling berperan penting dalam memuaskan konsumen produk private label indomaret. Maka dengan demikian perusahaan sebaiknya menjaga konsistensi dalam menentukan kebijakan harga yang sesuai dengan kualitas produk yang diberikan. Sehingga dapat mendorong minat konsumen untuk membeli kembali produk private label tersebut.

3. Diharapkan dalam penelitian selanjutnya untuk mengkaji variabel- variabel lain yang dapat mempengaruhi minat membeli ulang konsumen pada produk private label, sehingga memunculkan banyak temuan baru untuk dijadikan pedoman penelitian di masa yang akan datang.

\section{DAFTAR PUSTAKA}

Aaker, D.A. (1997). Should You Take Your Brand to Where the action is. Harvard Business Review, Vol. 75: 135-143

Alimah, R.N. (2017). Pengaruh Atmosfer Toko, Atribut Toko dan Citra Toko terhadap Minat Beli Konsumen pada Artha Buana Mart. Jurnal SimkiEconomic, Vol. 1 (5)

Anderson, Eugene W., Claes Fornell, dan Donald R. Lehmann. (1994). Customer Satisfaction, Market Share, and Profitabiliy : Finding from Sweden, Journal of Marketing, Vol. 58, p.53-66

Anggoro, W. (2016). Peran Persepsi Nilai (Perceived Sacrifice, Monetary Value, Convenience Value, Emotional Value, dan Social Value) terhadap Kepercayaan dan Minat Beli Ulang yang Dimoderasi oleh Kepuasan pada Toko Online Lazada di Indonesia. Jurnal, Fakultas Ekonomi Universitas Islam Indonesia

Bao, Yongchuan Yeqin. Bao, Shibin Sheng. (2011). Motivating Purchase of Private Brands: Effects of Store Image, Product Signatureness, and Quality Variation. Journal Business Reseacrh Elsevier 
Beneke, J., Ryan Flynn, Tamsin Greig and Melissa Mukaiwa. (2013). The Influence of Perceived Product Quality, Relative Price and Risk on Customer Value and Willingness to Buy: A Study of Private Label Merchandise. South Africa: Journal of Product and Brand Management

Cahyono, T.D. dan Al-Bari. (2016). Analisis Pengaruh Persepsi Kualitas dan Persepsi Nilai terhadap Kepuasan Konsumen dan Minat Beli Ulang (Studi pada Konsumen Indomaret di Kecamatan Depok Sleman. Jurnal Tambora, Vol. 1 (3):11-24

Hasanah, N. (2017). Persepsi Konsumen terhadap Produk Private Label Indomaret (Studi pada Indomaret Banjarmasin Kelurahan Benua Anyar). Jurnal Ilmu Sosial dan Humaniora, Vol. 3 (2)

Hellier, P.K., Geursen, G.M., Carr, R.A. and Rickard, J.A. (2003). Customer Repurchase Intention. A General Structural Equation Model. European Journal of Marketing, Vol. 37 (11/12): 1762-1800

Hidayat, I., dan Karneli, O. (2018). Pengaruh Kualitas Pelayanan, Citra Toko, dan Suasana Toko terhadap Minat Beli Konsumen (Survey Konsumen pada SB Houseware, Bukittinggi). JOM FISIF, Vol. 5

Jen, William and Kai-Chieh Hu. (2003). Aplication of Perceived Value Model to Identify Factors Affecting Passengers' Repurchase Intentions on City Bus : a Case of the Taipe Metropolitan Area. Transportation p307-p327. Netherlands: Kluwer Academic Publishers

Kotler, P. (2009). Manajemen Pemasaran, Analisis Perencanaan, Pengendalian, Prentice Hall, Edisi Bahasa Indonesia, Jakarta: Salemba 4

Kotler, P. dan Keller, K.L. (2007). Manajemen Pemasaran, Jilid 1. Edisi Bahasa Indonesia. Jakarta: PT Indeks

Kotler, P. dan Armstrong, G. (2008). Prinsip-Prinsip Pemasaran, Jilid 1, Edisi 12. Jakarta: Erlangga

Kusdyah, I. (2012). Persepsi harga, Persepsi merek, persepsi nilai, dan Keinginan Pembelian Ulang Jasa Clinic Kesehatan (Studi Kasus Erna Clinic Surabaya). Jurnal Manajemen Pemasaran, Vol. 7 (1)

Li, Huaiqin \& Jinhwan Hong, (2013). Factors Influencing Consumers' Online Repurchasing Behavior: A Review and Research Agenda, iBusiness, Vol. 5: 161166

Lilijander, V., Polsa,P., and Van Riel, A. (2009). Modelling Consumers Responses to an Appareal Store Brand: Store Image as a Risk Reducer. Journal of Retailing and Consumer Service, Vol. 16. (4): 281-290

Liu, Chih-Hsing Sam, Tingko Lee. (2016). Service quality and price perception of service: Influence on word-of-mouth and revisit intention. Journal of Transport Management, Vol. 52: 42-54

Lupiyoadi, R. 2006. Manajemen Pemasaran Jasa. Edisi Revisi. Jakarta: Salemba Empat.

Manullang, I.M. (Tidak Ada Tahun). Pengaruh Persepsi Kualitas dan Kepuasan Pelanggan terhadap Minat Beli Ulang Pasta Gigi Pepsodent (Studi Kasus Mahasiswa Fakultas Ekonomi Unika Santo Thomas Sumatera Utara). Artikel Penelitian, Fakultas Ekonomi, Unika Santo Thomas Sumatera Utara

Ningsih, E.S. (2017). Analisis Pengaruh Persepsi Harga dan Persepsi Kualitas Produk terhadap Minat Beli Baju Eceran di Solo Square. Artikel Penelitian, Fakultas Ekonomi dan Bisnis, Universitas Muhammadiyah Surakarta 
Ramadhan, M.D. (2018). Minat Membeli pada Produk Private Label: Pengaruh Faktor Persepsi Harga, Persepsi Kualitas, Citra Merek, dan Citra Toko "Studi Pelanggan Hypermart di Yogyakarta. Naskah Publikasi. Fakultas Ekonomi, Universitas Islam Indonesia

Raza, M. A., Nabeel, A., Awan, H. M., \& Khuram, S. S. (2012). Relationship Between Service Quality, Perceived Value, Satisfaction, and Revisit Intention in Hotel Industry. Interdisciplinary Journal Of Contemporary Research In Business, Vol. 4 (8), 788-805

Sahin Azize, Cemal Zehir, \& Hakan Kitapci. (2012). The Effects of Brand Experience,Trust, and Satisfaction on Building Brand Loyalty: An Empirical Research on Global Brands, International Strategic Management Conference, Elsiver Ltd.,Edition 7th, Procedia Social and Behavioral Science

Simamora, B. (2003). Panduan Riset Perilaku Konsumen. Jakarta: PT Gramedia Pustaka Utama

Tatik, S. (2008). Perilaku Konsumen : Implikasi pada Strategi Pemasaran. Edisi Pertama. Jakarta: Graha Ilmu

Tjiptono, F. (2011). Manajemen Jasa. Yogyakarta: Andi. . (2008). Strategi Bisnis Pemasaran. Yogyakarta: Andi.

Wang, Ya-Hui \& Li-Yan Chen. (2016). An Empirical Study of The Effect of Perceived Price on Purchase Intention Evidence from Low-Cost Carriers. International Journal of Business and Social Science, Vol.7 (4) Department of Business Administration. National Chin-Yi University of Technology: Taiwan

Yongchuan Bao, Shibin Sheng, Yeqing Bao, dan Stewart, David. (2011). Accesing Quality Perception of Private Label: Intransient Cues and Consumer Characteristicts. USA: Journal of Consumer Marketing 